\title{
A new cytotype for the El Carrizo deer mouse Peromyscus ochraventer
}

\author{
Irma Urbina Sánchez', María de los Angeles Aguilar \\ Santamaría ${ }^{2 \star}$ and Gerardo López-Ortega $\mathbf{M}^{1}$ \\ 'Biology Department, Universidad Autónoma Metropolitana Iztapalapa, México \\ ${ }^{2}$ Health Sciences Department, Universidad Autónoma Metropolitana Iztapalapa, México
}

Received: 25 September, 2020

Accepted: 20 October, 2020

Published: 21 October, 2020

*Corresponding author: María de los Angeles Aguilar Santamaría, Health Sciences Department, Universidad Autónoma Metropolitana Iztapalapa, México. Av. San Rafael Atlixco 186, Col. Vicentina, 09340 Iztapalapa, CDMX, Mexico, Tel: +52 15543414958 ;

Email:maas@xanum.uam.mx

Keywords: Karyotype; Pericentric inversion; Deletion; Monoarmed; Biarmed

https://www.peertechz.com

Check for updates

\begin{abstract}
Peromyscus ochraventer is a rodent species endemic of Mexico. In 1981, Robbins and Baker described its karyotype from one single female which presented $2 \mathrm{n}=$ 48 and $\mathrm{FN}=60$. In this paper we describe the $Y$ chromosome of the male and a new cytotype for the species, $2 \mathrm{n}=48, \mathrm{FN}=58, \mathrm{that}$ was identified in all of the collected specimens. The FN = 58 is due to one pericentric inversion in chromosome 6, as shown by G-banding pattern.
\end{abstract}

\section{Abbreviations}

2n: Diploid number; FN: Fundamental Number; m: meters; A: Acrocentric; B: Biarmed; B': Biarmed with deletion

\section{Introduction}

El Carrizo deer mouse is a rodent endemic to the Sierra Madre Oriental, Mexico, which inhabits in humid forests between 400 and $1500 \mathrm{~m}$, in three discontinuous areas of Tamaulipas and San Luis Potosí states [1]. P. ochraventer has been assigned to the mexican group of the genus Peromyscus based on morphological, anatomical and ecological traits [24]. In 1981, Robbins and Baker [5] described the karyotype of $P$. ochraventer from a female specimen collected in southern San Luis Potosí at the limit of its distribution, which had a diploid chromosome number $2 \mathrm{n}=48$ and a fundamental number FN $=60$. The purpose of this paper is to describe a new cytotype found in specimens from three populations located in the north, center and south of the species distribution.

\section{Methods}

Thirty-five specimens were collected in 3 different localities: Tamaulipas, Rancho El Cielo, 5 \& and 4 \&; San Luis Potosí, Maguey de Oriente 10 \& and 10 ఠP, Copalillo 3 \& and 3 $\&$ (Figure 1). Somatic metaphases were prepared according to
Baker, et al. 2003 [6]. The diploid number, 2n, was determined by examining an average of 50 mitotic metaphases from each individual. Karyotypes were prepared with 5 mitoses of excellent quality from each organism, photographed with an Olympus 7.5X zoom digital camera and a Zeiss 100X microscope objective. The chromosomes were arranged according to the Peromyscus Chromosome Standardization Committee [7] and described following Patton's classification criteria [8]. G-bands were obtained following the procedure of Wang and Federof [9]. The karyotype of this species was compared with that described by Robbins and Baker [5] and with those of some species that are part of the groups to which this rodent has been assigned.

\section{Results and discussion}

The 175 metaphases analyzed revealed that $P$. ochraventer showed a conservative karyotype along its distribution. The chromosomal and fundamental numbers found are $2 n=48$ and $F N=58$, respectively. Pairs 1, 2, 3, 9 were submetacentric, 4-8, 10-21 acrocentric and pairs 22, 23 were metacentric; the $\mathrm{X}$ chromosome was a large submetacentric. The $\mathrm{Y}$ chromosome resulted to be a small acrocentric one with two heterochromatic bands, one close to the centromere and the other in the distal part (Figure 2A). All of the specimens from the 3 populations examined in this study shared the same G-banding pattern (Figure $2 \mathrm{~B}$ and $2 \mathrm{C}$ ). 


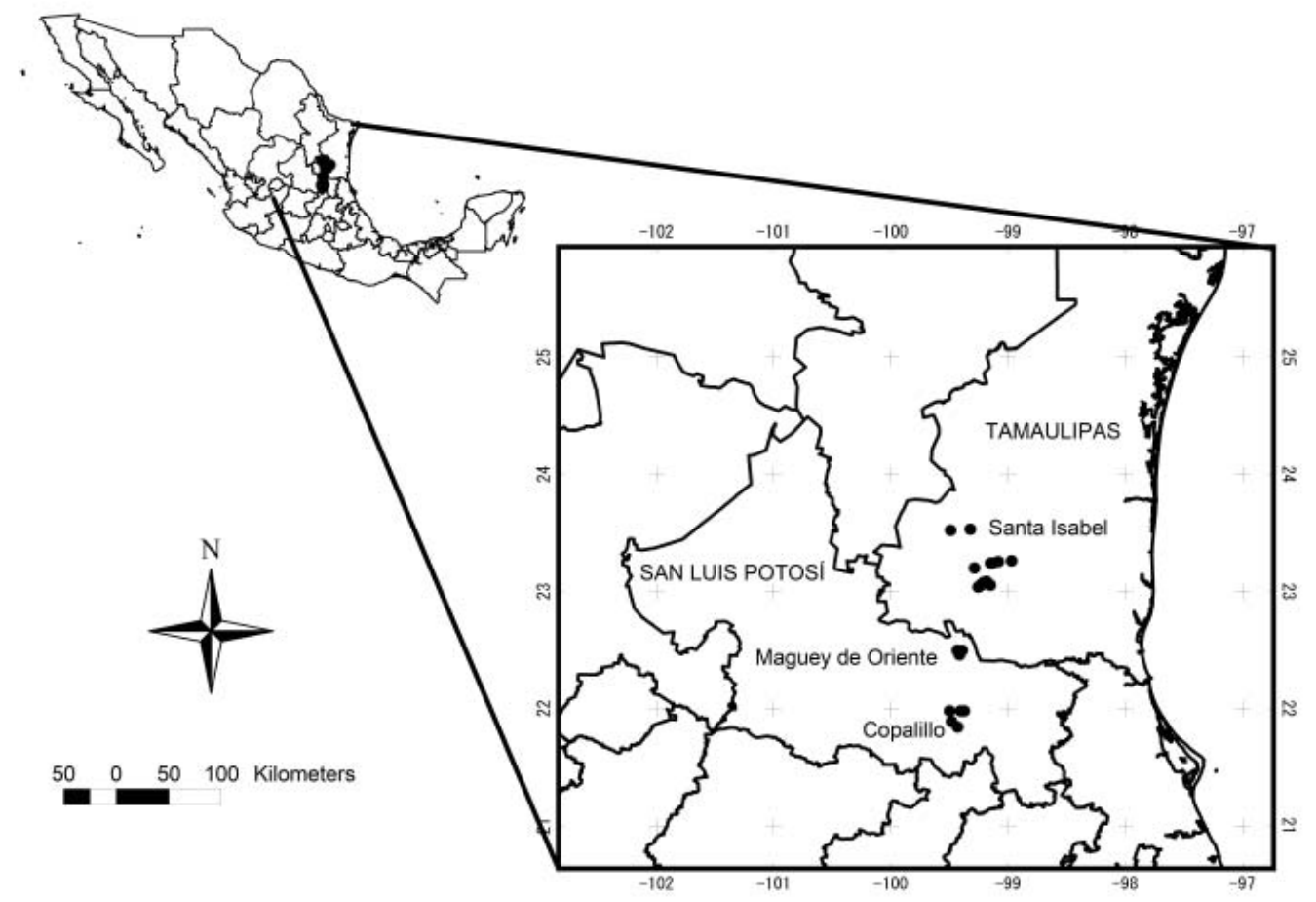

\section{. B H H} ：

Figure 2: New cytotype of $P$. ochraventer. 2A Karyotype of $P$. ochraventer with conventional staining. 2B G-Banding pattern of the new cytotype of $P$. ochraventer. $2 \mathrm{C}$ Ideogram with $\mathrm{G}$ bands.

The karyotype reported here, like that of Robbins and Baker [5] presented the primitive condition of the Peromyscus genus with chromosomes 1, 22 and 23 biarmed but differs in the condition of par 6 , resulting in the presence of 2 cytotypes for this species. Of the 36 specimens studied so far, pair 6 is acrocentric in 35 of them (this paper) and only in one it is submetacentric [2]. Based on the G-bands of pair 6, the difference between the two cytotypes can be explained by the occurrence of one pericentric inversion. In both karyotypes this chromosome has 4 bands but with different distribution. In that of Robbins and Baker [5], there is 1 band in the short arm and 3 more in the long arm. In the cytotype here described, the same 4 bands are in the long arm. Our results agree with Rogers, et al. [10] who reported that pericentric inversions are the most frequently chromosomal rearrangement found among the species of genus Peromyscus.
The common form of pair 6 is the Acrocentric one (AA) reported in $P$. guatemalensis, $P$. gymnotis, $P$. mexicanus, $P$. yucatanicus, $P$. zahrynchus, $P$. furvus, $P$. megalops, P. melanurus, P. nudipes, $P$. perfulvus, P. melanophrys, P. gratus, P. difficilis, $P$. pectoralis, $P$. beatae, $P$. crinitus, $P$. polionotus and $P$. boylii $[1,10-$ 21].

A second homomorphic form has been described: the submetacentric one (BB). In the cytotype of $P$. ochraventer described by Robbins and Baker [5] pair 6 shows this condition which is also found in P. maniculatus [14-16,22,23].

One heteromorphic condition of chromosome $6(\mathrm{AB})$ is observed in P. levipes [18] and P. maniculatus [14-16, 22,23].

It has also been observed that chromosome 6 is prone to suffer other kind of rearrangements. In addition to pericentric 
inversions, several authors have reported that in some species deletions ( $\mathrm{B}^{\prime}$ ) in the same pair have occurred giving rise to two more conditions: $\mathrm{AB}^{\prime}$ and $\mathrm{B}^{\prime} \mathrm{B}^{\prime}$. P. maniculatus [14-16,22-23]. P. oreas and $P$. sitkensis $[1,10,19]$, show the first form $\left(A B^{\prime}\right)$; the second one has been registered in P. melanotis [14-16].

Greenbaum and Baker [14] reported that the centromere position in the Y chromosome is variable. In P. ochraventer this chromosome is acrocentric like in other species of the mexicanus group: P. mexicanus, P. guatemalensis and P. zarhynchus [19]. The G-banding pattern showed two bands, one in distal position and the other close to the centromere.

Along its taxonomical history, P. ochraventer was related most frequently to the mexicanus species group until this species was assigned to the incertae sedis position by Musser and Carleton [24].

Bradley, et al. [25] based on the mitochondrial cytochrome-b sequences analysis found that $P$. ochraventer is related to the group truei, more closely to the clade truei which include $P$. gratus and $P$. truei species. However, the taxonomic position of $P$. ochraventer remained uncertain.

The karyotype of the species of the truei group shows variation in the number of chromosomes with two arms ranging from 5 to 8 . The cytotype of $P$. ochraventer described in this paper is similar to that of $P$. gratus, except for the biarmed pair 4 of this species [26]. Another similitude is the occurrence of more than one cytotype in $P$. ochraventer as it is reported for P. nasutus, P. truei [27] and P. difficilis [28]. Nevertheless, the karyotype of $P$. ochraventer here described is similar to the one found in the mexicanus group which is the same in all of the species included in this group [19].

We propose that the characteristic karyotype of $P$. ochraventer is the one described in this paper, whereas that reported by Robbins and Baker [5] based on a single female specimen can be considered as a polymorphism due to the variability of chromosome 6 .

\section{Acknowledgements}

We appreciate the support during field work to MVZ José Trinidad Sierra Guzmán, as well as to local authorities who kindly accompanied us to the collection sites: Ejido de Sta. Isabel, Tamps. Mr. Casiano Puga; Maguey de Oriente, Mr. Rodrigo Méndez, Mr. Rosalío Méndez and Mr. Mario Martínez; and Mr. Vicente from Copalillo, S.L.P.

\section{References}

1. López-Ortega G, Aguilar SMA, Hernández HA, Vargas MB (2003) Distribución actual de Peromyscus ochraventer en la Sierra Madre Oriental, México. Vertebrata Mexicana 12: 17-28.

2. Hooper ET, Musser GG (1964) Notes on classification of the rodent genus Peromyscus. Occas. Papers Mus Zool Univ Michigan 635: 1-13. Link: https://bit.ly/3dHvVRb

3. Hooper ET (1968) Classification. In: King JA (Ed.), Biology of Peromyscus (Rodentia). Spec Publ Amer Soc Mammal 27-74.
4. Huckaby DG (1980) Species limits in the Peromyscus mexicanus group (Mammalia: Rodentia: Muroidea). Contrib Sci Nat Hist Mus Los Angeles County 326: 1-24

5. Robbins LW, Baker RJ (1981) An assessment of the nature of chromosoma rearrangements in 18 species of Peromyscus (Rodentia: Cricetidae). Cytogenet. Cell Genet 31: 194-202. Link: https://bit.ly/3m44WCt

6. Baker RJ, Hamilton M, Parish DA (2003) Preparations of mammalian karyotypes under field conditions. Occ papers Mus Tex Tech Univ 228: 1-8. Link: https://bit.ly/34bwu2w

7. Greenbaum IF, Gunn SJ, Smith SA, McAllister BF, Hale DW, et al. (1994) Cytogenetic nomenclature of deer mice, Peromyscus (Rodentia): revision and review of the standardized karyotype. Cytogenet Cell Genet 66: 181-195. Link: https://bit.ly/34f87kC

8. Patton JL (1967) Chromosome studies of certain pocket mice genus Perognathus (Rodentia: Heteromyidae). J Mammal 48: 27-37. Link: https://bit.ly/3m3qZZR

9. Wang HC, Federoff S (1972) Banding in human chromosomes treated with trypsin. Nat New Biol 235: 52-53. Link: https://go.nature.com/3oiEcjE

10. Rogers DS, Greenbaum F, Gunn SJ, Engstrom MD (1984) Cytosystematic value of chromosomal inversion data in the genus Peromyscus (Rodentia: Cricetidae). J Mammal 65: 457-465. Link: https://bit.ly/2FleKIZ

11. Alvarez-Castañeda ST, González-Ruiz N (2008) Análisis preliminar de las relaciones filogenéticas entre los grupos de especies del género Peromyscus. In: Lorenzo C, Espinoza Medinilla E and Ortega J (Eds.), Avances en el Estudio de los Mamíferos de México II. San Cristobal de las Casas, Chiapas, México: Asociación Mexicana de Mastozoología: El Colegio de la Frontera Sur 5-26. Link: https://bit.ly/35jnasK

12. Arrighi FE, Stock AD, Pathak S (1976) Chromosomes of Peromyscus (Rodentia: Cricetidae) V. Evidence of pericentric inversions. Chromosomes Today 5: 323 329.

13. Davis KM, Smith SA, Greenbaum IF (1986) Evolutionary implications of chromosomal polymorphisms in Peromyscus boylii from southwestern Mexico. Evolution 40: 645-649. Link: https://bit.ly/2TcvqW1

14. Greenbaum IF, Baker RJ (1978) Determination of the primitive karyotype for Peromyscus. J Mammal 59: 820-834. Link: https://bit.ly/3jeGDzV

15. Greenbaum IF, Baker RJ, Bowers JH (1978) Chromosomal homology and divergence between sibling species of deer mice: Peromyscus maniculatus and $P$. melanotis (Rodentia: Cricetidae). Evolution 32: 334-341. Link: https://bit.ly/3ob65K6

16. Greenbaum IF, Baker RJ, Ramsey PR (1978) Chromosome evolution and the mode of speciation in three species of Peromyscus. Evolution 32: 334-341. Link: https://bit.ly/3dJCnah

17. Modi WS, Lee MR (1984) Systematic implications of chromosomal banding analyses of populations of Peromyscus truei (Rodentia: Muridae). Proc Biol Soc Wash 97: 716-723. Link: https://bit.ly/3m4H6Xm

18. Smith SA (1990) Cytosystematic evidence against monophyly of the Peromyscus boylii species group (Rodentia: Cricetidae). J Mammal 71: 654667. Link: https://bit.ly/3m0gjvd

19. Smith SA, Bradley RD, Greenbaum IF (1986) Karyotypic conservatism in the Peromyscus mexicanus species group. J Mammal 67: 584-586. Link: https://bit.ly/3ke7VI5

20. Stangl FB, Baker RJ (1984) Evolutionary relationships in Peromyscus: Congruence in chromosomal, genic and classical data sets. J Mammal 65: 643-654. Link: https://bit.ly/31IR12Q

21. Zimmerman EG (1974) Chromosomes of the Mexican plateau mouse Peromyscus melanophrys, and a new sex-determining mechanism in mammals. Can J Genet Cytol 16: 797-804. Link: https://bit.ly/3keFRnR

Citation: Sánchez IU, Angeles Aguilar Santamaría MDL, Gerardo López-Ortega M (2020) A new cytotype for the El Carrizo deer mouse Peromyscus ochraventer. Glob 
22. Bradshaw WN, Hsu TC (1972) Chromosomes of Peromyscus (Rodentia: Cricetidae) III Polymorphism in Peromyscus maniculatus. Cytogenetics 11: 436-451. Link: https://bit.ly/2IN7Gpv

23. Greenbaum IF, Reed MJ (1984) Evidence for heterosynaptic pairing of the inverted segment in pericentric inversion heterozygotes of the deer mouse (Peromyscus maniculatus). Cytogenet. Cell Genet 38: 106-111. Link: https://bit.ly/2HgezyO

24. Musser GG, Carleton MD (2005) Superfamily Muroidea. In: Wilson DE Reeder DM, Eds. Mammal species of the world: a taxonomic and geographic reference. Vol. 3rd (pp 894-1531) Ed. Baltimore, Maryland: Johns Hopkins University Press.

25. Bradley RD, Durish ND, Rogers DS, Miller JR, Engstrom MD, et al. (2007) Toward a molecular phylogeny for Peromyscus: evidence from mitochondrial cytochrome-b sequences. J Mammal 88: 1146-1159. Link: https://bit.ly/2IN8JFX

26. Martínez-Vázquez J, Vela MMA, González MRM (2020) Análisis cromosómico de Perrmyscus gratus (Cricetidae) de Tecamachalco, Puebla, México. BIOCYT 12: $909-917$.

27. Hsu TC, Arrighi FE (1968) Chromosomes of Peromyscus (Cricetidae) 1. Evolutionary trends in 20 species. Cytogenetics 7: 417-466. Link: https://bit.ly/2HjdıO5

28. Arellano-Meneses AG, Hernández-Carbajal LA, Lira-Galera IE, Ruiz-Guzmán G, Mudespacher-Ziehl C (2000) Karyotypical studies on Peromyscus difficilis amplus (Rodentia: Muridae). Cytologia 65: 25-28. Link: https://bit.ly/3kfRTOj

\section{Discover a bigger Impact and Visibility of your article publication with}

\section{Peertechz Publications}

\section{Highlights}

* Signatory publisher of ORCID

* Signatory Publisher of DORA (San Francisco Declaration on Research Assessment)

* Articles archived in worlds' renowned service providers such as Portico, CNKI, AGRIS, TDNet, Base (Bielefeld University Library), CrossRef, Scilit, J-Gate etc.

- Journals indexed in ICMJE, SHERPA/ROMEO, Google Scholar etc.

* OAI-PMH (Open Archives Initiative Protocol for Metadata Harvesting)

* Dedicated Editorial Board for every journal

* Accurate and rapid peer-review process

* Increased citations of published articles through promotions

* Reduced timeline for article publication

Submit your articles and experience a new surge in publication services (https://www.peertechz.com/submission).

Peertechz journals wishes everlasting success in your every endeavours.

Copyright: ( 2020 Sánchez IU, et al. This is an open-access article distributed under the terms of the Creative Commons Attribution License, which permits unrestricted use, distribution, and reproduction in any medium, provided the original author and source are credited. 